\title{
ASSESSMENT OF OFFICIAL BOND AS AN INTANGIBLE ASSET AND ITS IMPLICATIONS ON THE RESTITUTION OF STATE LOSSES DUE TO VIOLATIONS AGAINST THE OFFICIAL BOND AT THE MINISTRY OF FINANCE
}

\author{
Mila Mumpuni* \\ Ade Sonny Martin \\ Sekolah Tinggi Keuangan Negara
}

\begin{abstract}
Official Bond is a common form of engagements in an education institution funded by an agency. The engagements result that the granted parties must work for a certain period. The violation against this official bond will cause disadvantages for the agency that has funded the educational process that is subject to claims for compensation against the offending party. One of the government agencies that implement the official bond is the Ministry of Finance. Based on the data from 2010-2014, the state losses due to the violations against the Official Bond in the Ministry of Finance showed less optimal performance. One of important obstacles in the completion of the bond violations is the difficulty in determining the value of the state losses. This paper aims to develop the possibilities of the Official Bond recorded as an Intangible Asset and its implications toward the restitution of the state losses due to the violations against the official bond at the Ministry of Finance.
\end{abstract}

Keywords: Official Bond; State Losses; Compensation Claims; Intangible Asset

\section{INTRODUCTION}

Like the private companies, the government may experience losses in carrying out its activities. In term of losses due to negligence or intentional misconduct of any parties, the state is entitled and obliged to carry out the compensation claim. As a part of the government, the Ministry of Finance has also made efforts to claim the state losses in its surrounding environment. The state losses can be caused by either Treasurer or non Treasurer, done intentionally or negligently (Antoro, 2015). However, based on the data from the Progress Report on the state losses of the Ministry of Finance, it is shown that the efforts for the restitution are still not yet optimal. One type of the state losses that should be more focused on is the loss due to the violations against the official bond. This is because the value and number of the cases are getting increased but not matched with the restitution. The progress of the value and number of the losses and level of the restitution are presented in Figure 1. 

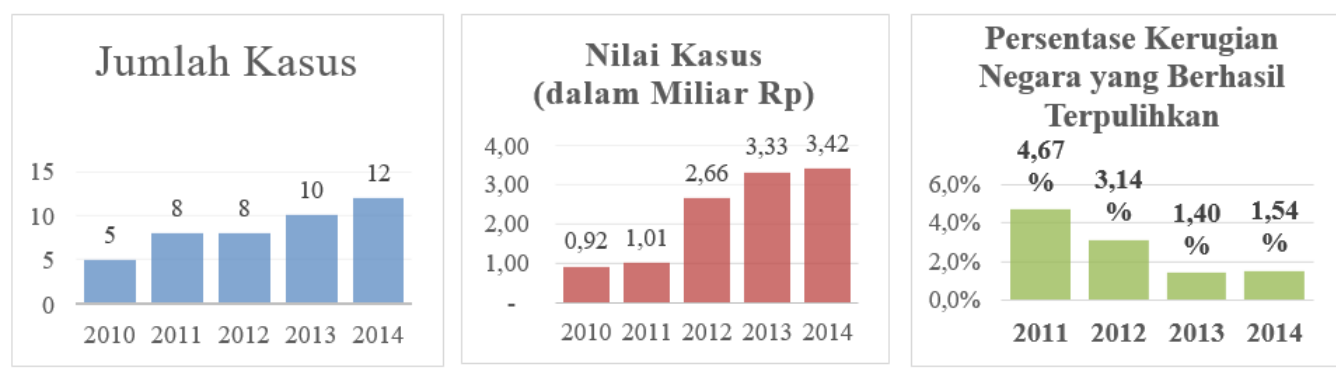

Jumlah kasus $=$ number of cases Nilai kasus $=$ values of cases (in IDR billions)

Presentase kerugian Negara terpulihkan = percentage of successful restitution

\section{Figure 1}

Progress of the State Losses in form of Violations against the Official Bond in the Ministry of Finance for fiscal year $2010-2014$

Source: adapted from the Progress Report of State Losses of the Ministry of Finance for fiscal year 2014 and Information Media of the Ministry of Finance on the State Losses for fiscal year 2013, the Secretariat of the Directorate General of the Ministry of Finance.

Martin (2015) has conducted a research on the state losses due to the violations against the official bond in the Ministry of Finance. One focus of this research is about certain obstacles encountered during the restitution process. The results show that the main obstacle is related with the difficulty in determining the amount of losses value that should be replaced by the bond violators. If the state losses due to the violations against the official bond in the Ministry of Finance show unexpected trend, it is quite different from the losses due to the lost of State Properties in form of official vehicles. The data from 2010- 2013 showed that the rate of restitution is high (over 40\%), although the number and value of the losses tend to increase each year (presented in Figure 2).

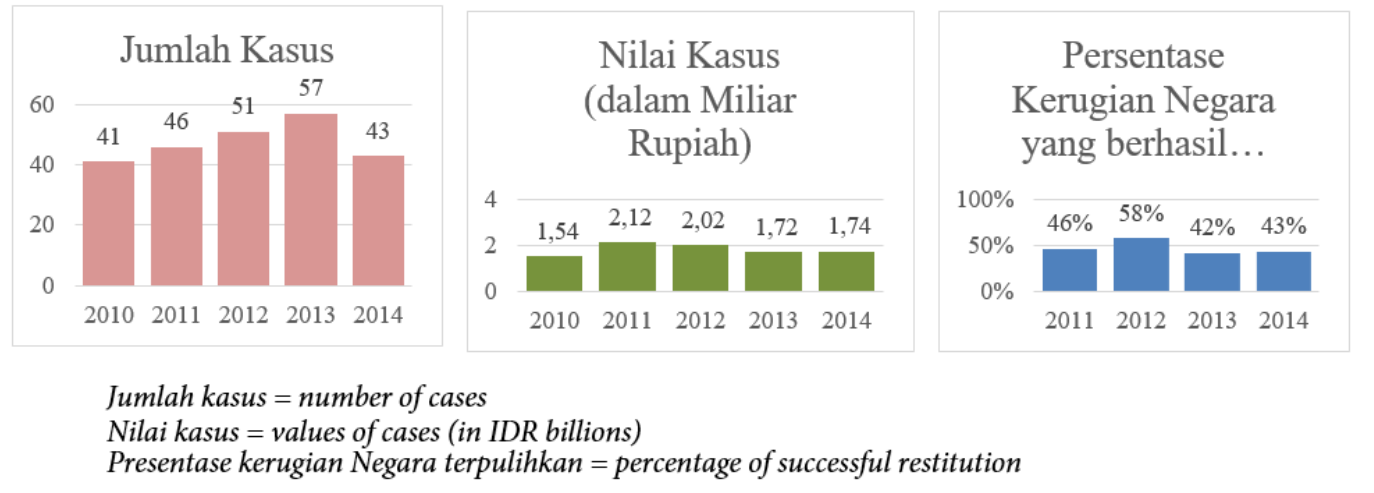

Figure 2

Progress of the State Losses on Official Vehicles in the Ministry of Finance from fiscal year 2010-2014 
Source: adapted from the Progress Report of State Losses within the Ministry of Finance for fiscal 2014 and Information Media of the Ministry of Finance on the State Losses for fiscal year 2013, the Secretariat of the Directorate General of the Ministry of Finance.

A basic difference between the restitution of the state losses due to the violations against the Official Bond and State Properties lies on the method used in determining the amount of value that should be returned. In general, the amount of state losses for State Properties is calculated using fair market value. In case of unidentified fair market value, it is possible to use the remaining carrying value of State Properties. It can accelerate the process of calculating the amount of state losses due to State Properties cases. This method cannot be applied in calculating the state losses due to the violations against the official bond because until now, it is not recorded as an asset. The potential of ease in calculating the value of the state losses due to the violations against the official bond in the Ministry of Finance categorized as an asset is somehow an interesting case for further investigation. Therefore, the author tries to develop an idea about a possibility of recording the bond as a government's asset and its implications for the restitution of the state losses related with the violations of the official bond. This research is conducted through the literary review (library research). Based on the backgrounds above, the conceptual framework of this article is shown in Figure 3 below.

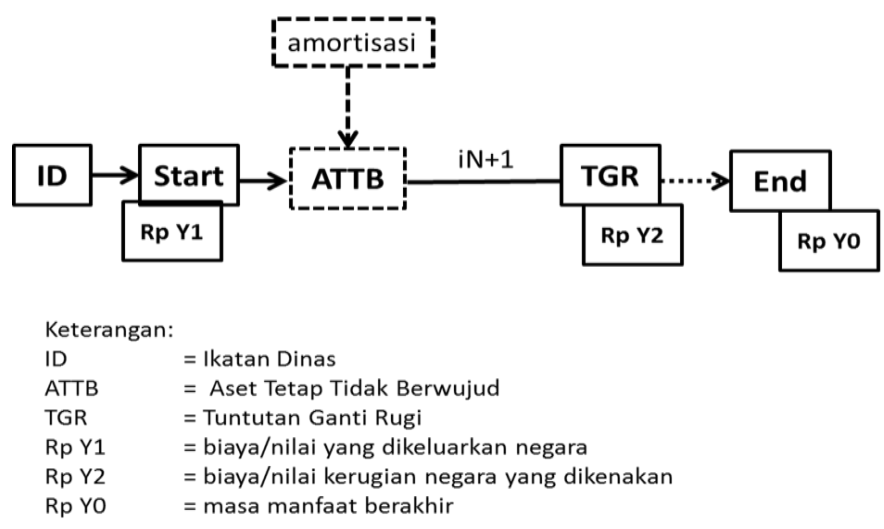

Ikatan dinas $=$ official bond

Aset Tetap Tak Berwujud = intangible assets

Tuntutan Ganti Rugi = compensation claim

Biaya/nilai yang dikeluarkan negara $=$ state expenditure

Biaya/nilai kerugian yang dikenakan = value of restitution

Masa manfaat berakhir = last beneficial period

Figure 3

Conceptual Framework of the Research

Source: adapted by the authors

The Official Bond Engagement has been officially applied when the students have completed their compulsory education and they must work during the predetermined official bond period. The value set at the beginning of this engagement is the value that should be indemnified by the students of the Official Bond as much as the costs incurred by the state. In case of the Official Bond can be classified as an intangible asset, the amortization can also be applied. In case of the violations against the Official Bond, the value of the state loss is equal with the carrying value of the Engagement of Official Bond. The definition of intangible asset according to FASB is "probable future economic benefits obtained or control by a particular 
entity as a result of past transactions or events", and this applies to all assets, and the difference only lies on the forms; the tangible assets have physical forms while the intangible ones do not have any forms.

Governmental Accounting Standards Statement (PSAP) 01 defines Intangible Assets as non-financial assets that can be identified and do not have a physical form and held for use in producing goods and/or services, or used for other purposes, including intellectual property rights. In the public sector accounting in Indonesia, accrual-based PSAP defines an asset as an economic resource controlled and/or owned by the government as a result of past events and from which the economic and/or social benefits in the future are expected to be obtained either by the government or the public, and can be measured in terms of money, including non-financial resources required to provide public services and maintained resources for historical and cultural reasons. Intangible assets are recognized if and only if: Most likely estimated for expected future economic benefits or potential services resulted from the intangible assets will be received/ enjoyed by the entity; and acquisition cost or fair value can be measured reliably. (KSAP: Technical Bulletin Number 11)

Furthermore, the Technical Bulletin number 11 reveals that an entity must assess the possibilities of expected future economic benefits or potential services using the support of logical assumptions that represent management's best estimate of the economic conditions that will be obtained during the economic life of the intangible assets. The entity uses those judgments to assess the degree of certainty of the flow of economic benefits in the future as a result of the use of intangible assets based on the evidences available at initial recognition, with more emphasis on external evidences.

As one of non-current assets, the intangible assets may experience value decrease during its beneficial period, or so-called amortization. Amortization is depreciation of intangible assets allocated systematically and rationally over its beneficial period. The intangible assets' beneficial period can be affected by various factors, all of which must be taken into account in the determination of the amortization period. Some factors to be considered in determining the intangible assets' beneficial period are: Legal stipulations, regulation, or contractual; Stipulations for renewal or extension; Effects of obsolescence, demands, competition, and other economic factors; The beneficial period may be parallel with the expectations of personal or groups' service period of the employees; The expected actions of competitors and others can limit the competitive advantages; The beneficial period that seems to be unlimited might in fact be able to be uncertain and its benefits cannot be projected properly. An intangible asset may consist of a combination of many individual factors with varied effective ages.

There are several methods of amortization, such as straight-line, declining balance and production units' method. The selection of the methods should be based on the patterns of expected economic benefits in the future applied consistently from period to period, unless there are changes in the estimate of the consumption patterns. In case that the patterns cannot be measured reliably, the straight-line method is used. An important thing to remember is that the amortization can only be done on the intangible assets that have limited beneficial period. (KSAP: technical bulletin 11).

The provision of education or training for employees and prospective employees can be considered as a form of investment of an institution. It is because the provision of education or training can lead to the 
increasing level of productivity, as has been investigated by Barron, Berger and Black (1993), Barron, Black and Loewenstein (1989) and Bishop (1988) (cited in Loewenstein and Spletzer, 1998). However, the provision of education or training has a risk for the agency itself in form of transfer of officials or candidates due to either natural factor (passed away) or not (resignation). Therefore, to reduce the risk of the investment losses, the providers of education or training can make an agreement which contains an obligation for the workers to restitute the cost of the education and training that have been incurred if they resign within a certain period (Von Bergen: 2007, 130 ). In Indonesia, this kind of agreement is known as an official bond agreement. The source of official bond can be generally divided into two categories: The Official Bond derived from the provision of education to prospective employees through official colleges, and; The Official bond coming from licensing the learning tasks to the employees.

As mentioned earlier, the establishment of official colleges and the provision of learning tasks are analogous to the investment made by the government. To keep the value of the investment effective/not to be wasted (i.e. resignation of the employees who have been educated), it is then made an official bond agreement. With the existence of this agreement, it is expected that the investment already been indemnified when the bond period has been completed. When there are parties who do not establish their duties during the bond period, then the stated is called as suffering a loss.

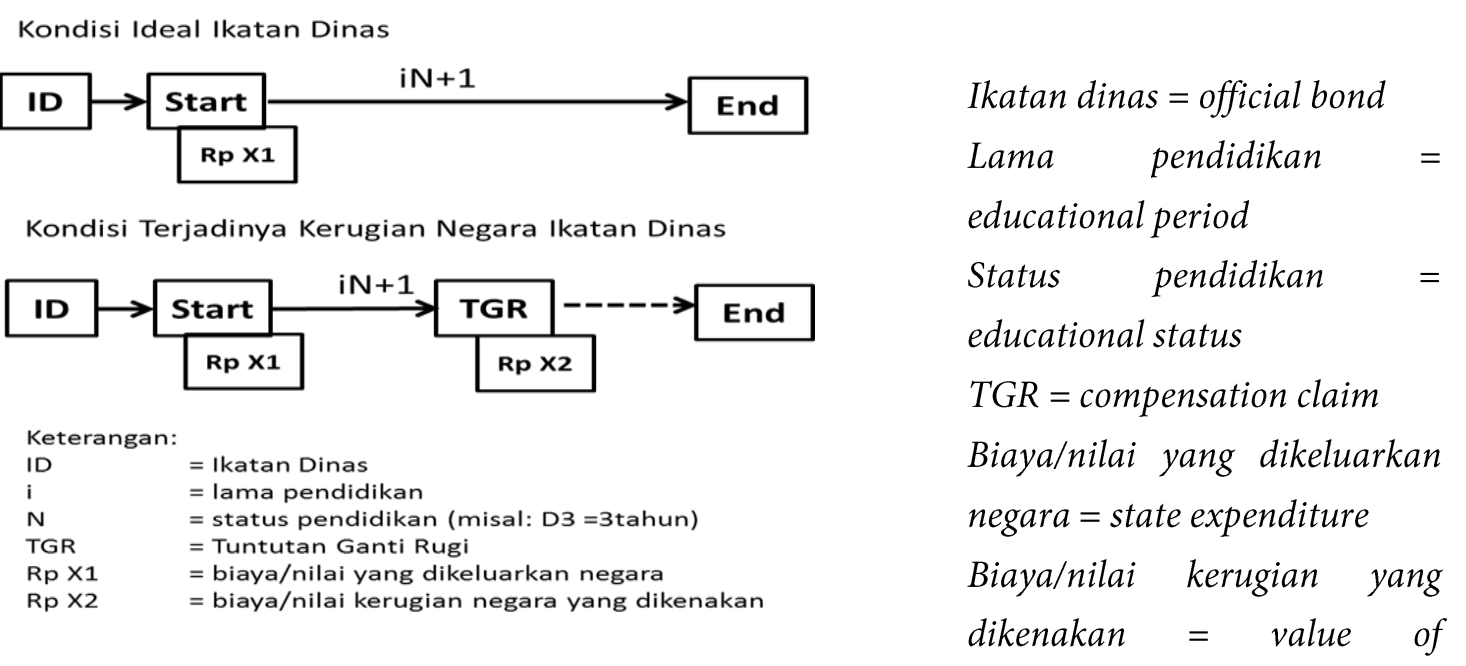

Figure 4

Conditions of Official Bond

Source: adapted by the author

Figure 4 presents a condition that may occur from the official bond engagement. An ideal condition of the official bond for both sides occurs if the bond period has been completely performed. This causes the entity which provides the education has received the expected benefits, and vice versa. However, this ideal condition may not be performed if there are any violations against the official bond. Viewed from the perspective of education providers, a bond violation will cause losses of benefits expected in the future. To indemnify these beneficial values, the violator must establish the restitution. 
The definition of State Loss is contained in Article 1 point 22 of Law No. 1 of 2004 (Pasal 1 angka 22 UU No 1 Tahun 2004) stating that "lack of money, securities, and goods, in real and definite numbers as a result of an unlawful act, either intentionally or negligent". Based on this understanding, it can be drawn some elements of the state losses as follows:

"The state loss is the reduction of state assets in form of money, securities, and property from their initial amount/number/values. Lack of state finance must be in real and definite numbers, or in other words, the loss really occurs with the amount of loss can be determined precisely, not only an indication or as a potential loss. The loss can occur as a result of an unlawful act (whether intentional or negligent) and unexpected circumstances beyond human control"

Kardjo (1994: 85) defined the restitution of the state losses as "the government's effort in reaction to the suffered losses for the restitution and to improve the stakeholders' bookkeeping ". It can be concluded that a state loss to can be said as completely resolved if: a) the loss has been indemnified, and, b) the bookkeeping has been improved well (no fatal mistakes/shortages). The restitution of the state losses can be settled out of the court, through administrative law. The restitution methods outside the judicial court are more effective and efficient than through the court (Saidi: 2013.136 to 137). It is said to be more effective and efficient because the procedures of the restitution to are not convoluted (there are no appeals and judicial review). The techniques of the restitution of the state losses have been using the administrative law have been set out in Chapter IX of Law No. 1 of 2004. The restitution of the state losses in the administrative law is done by the prosecution process. An important thing to remember is that not all losses can be claimed by the prosecution. The losses that can be claimed are those due to unlawful acts.

Mechanism of Reporting. The restitution of the state losses caused by the violations againts the official bond and lost state properties is done using a mechanism called Compensation Claims (TGR) with a legal basis KMK No. 508 / KMK.01 / 1999, last amended by Regulation of the Minister of Finance No. 213 / PMK.01 / 2014 (Peraturan Menteri Keuangan Nomor 213/PMK.01/2014). Chronology of the restitution of the state losses using Compensation Claims mechanism in the Ministry of Finance is started from identifying the losses by the Ministry of Finance and ends at State Receivable Affairs Committee (PUPN) when the claims toward the state losses are in a stagnation that should be collected in forcefulness. The Compensation Claims mechanism may involve many parties, so sometimes it quite takes a long time for its completion.

The restitution of the state losses using the Compensation Claims mechanism is initiated from an assessment/information regarding the occurrence of the state losses in an office/ unit. Based on this information, the Head of Unit must investigate whether the information is correct and has been qualified to be followed for the settlement of the losses. The assessment is then contained in form of Minutes of Investigation / Research (BAP), which aims to gain certainty about the number / amount of the losses, the parties that must be responsible for the losses and written evidences that can be accounted for. One way to gain certainty about the amount of the losses that have to be indemnified in case of the violations against the official bond is to check the terms of the official bond agreement (linked to the contract value, official bond period, etc.). Nevertheless, the bond contract is usually not included in the files of employees who are 
working in the units where the losses occur. This cause the head of the unit must correspond with those holding the contract.

Mechanism of Recording. In term of accounting records, the process of the official bond and the violations against the official bond can be further described as follows

Educational tuition

Operational Expenditure

Approximate Estimation of SAL Changes

$\mathrm{Xxx}$

$\mathrm{Xxx}$

Initial official bond period

Unrecorded

During official bond period

Unrecorded

During the violations against the official bond agreement

Unrecorded

When SKTM is signed or other similar documents are established

Paid compensation claim

PNBP

Paid compensation claim

Cash

Paid compensation claim
$\mathrm{Xxx}$

$\mathrm{Xxx}$

$\mathrm{Xxx}$

$\mathrm{Xxx}$

\section{METHODS}

The research on the Assessment of Official Bond as an Intangible Asset and Its Implications on the Restitution of State Losses Due to Violations against the Official Bond at the Ministry of Finance uses a qualitative method with the literature review and the object is the employees of the Official Bond institutions.

\section{RESULTS AND DISCUSSIONS}

Before going forward into the question of whether the Official Bond can be categorized as an intangible asset or not, it should be firstly explained whether the Official Bond can be categorized as a resource that meet the definition of an asset or not. Principally, it is already able to meet the criteria for the recognition as an asset of an organization or government agency. The definition of asset used in the accounting standards of the current government (which corresponds to the definition given by IASB) requires that to 
be recognized as an asset, a resource must be controlled by an entity, has a future economic benefits, as well as underlying past transactions.

The initial analysis of the Official Bond engagement is whether the Official Bond has future/prospective benefits for the government's entities that own it or not. Accounting Technical Bulletin number 11 explained that the future economic benefits is the potential of an asset to contribute directly or indirectly to the operational activities of the government in form of streams of revenue or expenditure savings for the government. The Official Bond engagement requires that the resources in form of employees must be well-educated for relevant government entities that contribute directly in the operational activities. The employees of the Official Bond institutions must work for public services that can be in form of creation of a revenue stream for the government or the government's austerity. For example, an employee of the Official Bond working at the Ministry of Finance is expected to contribute directly in managing the state finance. The forms of contributions must be in accordance with the assignments or authority given to every employee on each echelon 1 based on their duties and functions. It means the presence of the Official Bond engagement between the government and the employees has a real element of prospective economic benefits.

The Official Bond engagement causes each employee shall work on a government's entity for certain period specified in the agreement. This engagement binds the employees of the Official Bond to be under the control of the government's entity. In contrast to the employees without any official bond, the employees of the official bond can be said to be under the full control of a government's entity. This can be seen from the authority of government's entities to determine in what units/agencies the employee will be hired, forms of tasks that will be assigned, as well as decisions to lend or transfer the employees tied to other units / agencies (if necessary). Termination of the engagement is possible, but it will not make the entity as the contract holder loses its rights on the employees of the Official Bond without any adequate compensation. The Official Bond employees who decide to end the engagement before the Official Bond period is over are obliged to make restitution, as much as the rest of the contract value that they have not yet completed.

As the emergence of an asset in general, the engagement of the Official Bond arises from past transactions made by the government. The transactions are the government-issued economic sacrifices in financing the education of the Official Bond employees. Such transactions cause the outflow of economic benefits from the government's entities. The outflow of the economic resources is expected to provide future benefits for the government's entities. The prospective economic benefits are expected to arise from such expenditure accommodated in form of the Official Bond between the government's entities and the Official Bond employees. The discussions above suggest that the Official Bond can be categorized as an asset. In the government's accounting, assets are divided into two groups: current and non-current assets. The main difference between those two is the time when an entity expects to realize the asset. If the entity expects to realize the asset within 12 months after the reporting period, the asset will be classified as a current asset. Given that the realization of the Official bond is normally expected to be realized fully over 12 months, then the Official bond is classified into a non-current asset. 
The non-current asset is further divided into three groups, namely fixed, intangible, and financial assets that are long-term. Because the Official Bond is a resource that does not have a physical form and does not constitute financial asset (non-monetary), then the Official Bond is classified as an intangible asset. In addition to fulfilling the definition of Intangible Asset, the Official Bond must also meet several other criteria to be recognized as an Intangible Asset. One of the criteria, according to KSAP in Technical Bulletin 11 on Intangible Assets, is visibility. In addition, the technical bulletin also explains that something is recognized as an intangible asset if and only if it has greater possibilities to create prospective economic benefits expected to flow to the government as well as its cost or fair value can be measured reliably.

The visibility can be divided into two, i.e. an asset's ability to be separated from others and/or the asset rises from a binding contract. Under this circumstance, the official bond has met the visibility criteria required by the technical bulleting issued by KSAP. The Official Bond engagement can be identified separately from other government's assets, even essentially the Official Bond itself is not attached on other assets but itself. Thereby, the Official Bond can be basically exchanged or transferred in any other form, for example: private companies that want to hire some employees of the government's Official Bond can "buy" the Official Bond engagement to serve as the employees of the companies. Engagement Official Bond appears on an agreement that is legally binding. In a technical bulletin explained that the intangible assets in the form of intangible assets can be recognized regardless of whether those rights can be transferred or separated from the entity or from other rights and obligations

PSAK 19 explains that the intangible assets are initially recorded at their acquisition values. Presentation after the acquisition process uses the carrying value. The measurement, according to the technical bulletin on intangible assets, also explains the same thing. Viewed from the nature of the acquisition, the formation of the Official Bond engagement belongs to the intangible assets developed internally. The technical bulletin explains that the intangible assets acquired from the development of qualified recognition, the value of the acquisition is recognized as much as acquisition expenses including the expenses since the enactment of Intangible Assets for their prospective benefits in the future.

It is further explained that the Official Bond education institutions have cost components that can be clearly identified. The scholarships for the Official Bond students is budgeted with the amount that has been determined at the beginning of the study. The educational costs include tuition, research, and living cost according to the types of the scholarships. The costs incurred distributed directly by the government to the education providers can be clearly identified, for the implementation of the education is accompanied by the engagement and binding budget allocations.

The change of the Official Bond into an intangible asset will result in some changes in the mechanism of state losses restitution. It is due to when the Official Bond is recorded as an intangible asset, then the whole expenditure for obtaining the Official Bond should be recorded as capital expenditure, and thus the amortization is made. Therefore, this mechanism change will be easily identified from the perspective of the Official Bond recording/accounting. The following are illustrative of the journals created by the event related with the Official Bond.

For educational expenditure 


\author{
LRA Journal \\ Capital Expenditure \\ Xxx \\ Estimation of SAL Changes \\ $\mathrm{Xxx}$ \\ Accrual Journal \\ On-progress Intangible Asset \\ $\mathrm{Xxx}$ \\ Cash/Debt/etc. \\ $\mathrm{Xxx}$ \\ Early official bond period \\ Intangible Asset \\ Xxx \\ On-progress Intangible Asset \\ $\mathrm{Xxx}$ \\ During the official bond period \\ Charge for Intangible Asset Amortization \\ $\mathrm{Xxx}$ \\ Intangible Asset \\ $\mathrm{Xxx}$
}

The amortization is made proportionally (straight-line method) according to the beneficial period of the Official Bond

During the violations against the Official Bond

Other Assets

$\mathrm{xxx}^{*}$

Intangible Asset

Xxx

${ }^{*}$ As much as carrying value of Intangible Asset (acquisition value diminished by the amortization made)

When SKTM is signed or other similar documents are determined

Paid compensation claim

PNBP $\mathrm{xxx}^{*}$

\section{$\mathrm{Xxx}$}

* As much as carrying value of Intangible Asset (acquisition value diminished by the amortization made)

Paid compensation claim

Cash

$\mathrm{Xxx}$

Paid compensation claim

$\mathrm{Xxx}$

In term of reporting mechanism, an occurring change is no need for correspondence with the parties that hold the bond contract. This is because by looking into the accounting records on the Official Bond, it can be easily known how much the loss that must be indemnified by the offenders of the Official Bond. The value record of the intangible asset of the Official Bond should have attached/written by the units where the employees have the Official Bond engagement. This is because the Official Bond has been recorded as an 
intangible asset and it is already categorized as the state properties and must comply with the provisions of the state properties. One of the provisions is that state properties should be recorded in a place where they are available for use.

The benefits of the application of the intangible asset accounting on the official bond has been studied by Nur, Noor, and Harahap in 2014 in his paper entitled "Capitalization of Official Bond Contract as an Intangible Asset to Improve the Quality of Government Financial Statements". The main point explained in this paper is that the capitalization of the Official Bond Contract as an Intangible Asset is expected to provide the following benefits: Improving the reliability of government's reports; Improving the quality of decision-making; Transparency of public funds use; The recognition of the official bond as an asset on the balance sheet will increase awareness of the importance of a good contract management in the official bond; Assisting human resources management in order to optimize the educated human resources effectively; Avoiding the state losses due to smaller restitution than the actual expenditure.

Viewed from the restitution of the state losses, the official bond recording as an intangible asset is expected to give some benefits as follows: Accelerating the restitution process. The Official Bond recording as an intangible asset will be able to accelerate the process of the restitution of the losses related with the violations against the official bond. The restitution process will be faster, especially in determining the value of losses that should be indemnified. This is because the process of determining the value only needs the carrying value of the Official Bond which has been recorded in the Unit Accounting. In addition, the Head of Unit no longer needs to ask the parties who administer the bond contracts to determine whether an employee who has resigned/been fired still have the bond period to be completed or not. The process of determining the value of the state losses will be faster because the head of Unit does not have to ask the parties that hold the data regarding the presence or absence of the employees that will resign /be fired; Avoiding mistakes in determining the value of the state losses. The Official Bond recording as an intangible asset will also help in avoiding the occurrence of mistakes in determining the value of the state losses due to the official bond. This is because with the Official Bond recording as an intangible asset and the amortization made, the accuracy of the value can be more precise compared when the Official Bond has not yet been recorded; Meeting the definition of the state losses according to the Act. Act No. 1 of 2004 (Undang-Undang No 1 Tahun 2004) has defined the state loss "lack of money, securities, and goods in real and definite numbers as the result of an unlawful act, either intentionally or negligent". Currently, the losses due to the violations against the official bond are still difficult to be categorized as a lack of money, securities, and goods since the official bond itself is not recorded as a good/ asset. This causes difficulties in equalling the perception on why the violation against the official bond is included as the state losses; whether it is included as the lack of money, securities, or shortage of goods?

If the official bond has been recorded as an intangible asset, it is already eligible to be categorized as an asset. This causes the state loss due to the violation against the official bond is equivalent to the loss that occurs due to shortage of goods. Besides the potential for ease in recording the official bond as an intangible asset, it is also possible for the existence of some obstacles when the Official Bond is recorded as an intangible asset, such as: Difficulties in administering the official bond that has been running previously, 
Difficulties to split the costs included in the acquisition cost of the Official Bond. The Official Bond has not been set as an intangible asset on the central government's entities as it has been ruled the amortization on other intangible assets based on the Regulation of the Minister of Finance number 251 / PMK.06 / 2015 (Peraturan Menteri Keuangan No 251/PMK.06/2015)

\section{CONCLUSION}

Based on the discussion above, it can be drawn some conclusions. The Official Bond engagement has met the definition and recognition criteria of an intangible asset. This causes the Official Bond can be recorded as an intangible asset. There are some differences in the process of the restitution caused by the violations against the Official Bond, especially in determining the value of the losses that must be indemnified. After the Official Bond has been recorded as an intangible asset, the process of determining the value can simply use the carrying value when the state losses occur. The main benefit of recording the Official Bond as an intangible asset is the ease in determining the value of state losses.

Based on the studies conducted, the Official Bond recording as an intangible asset can be done by bringing some implications on the restitution process of the state losses. Most implications successfully captured by the authors are in forms of benefits that can be gained after the Official Bond has been recorded as an Intangible Asset. Therefore, the authors suggest that the Official Bond recording can be considered as one of the solutions for the restitution of the state losses caused by the violations against the official bond.

\section{REFERENCES}

Antoro, Setyawan Dwi. 2015. Penyelesaian Kerugian Negara Non Bendahara di Lingkungan Kementerian Keuangan. http://www.bppk.kemenkeu.go.id/publikasi/artikel/147-artikel-anggaran-dan-perbendaharaan/21158penyelesaian-kerugian-negara-non-bendahara-di-lingkungan-kementerian-keuangan

Ardiarini, Linda Ria. 2014. Aset Tetap Tidak Berwujud (tugas akhir) . http://dokumen.tips/documents/aset-tetap-takberwujud.html

Devi, Astri Prima. 2004. Akuntansi Untuk Pemain Sepak Bola. Jurnal Akuntansi dan Keuangan Indonesia. Vol. 1 pp. 38-53. http://jaki.ui.ac.id/index.php/home/article/viewFile/197/172

Amir, Eli \& Gilad Livine. 2005. Accounting, Valuation, and Duration of Football Player Contracts. Journal of Business $\begin{array}{llllll}\text { Finance } \quad \text { and } & \text { Accounting. } 32(3) \quad \& \quad \text { (1). April/May } 2005 . & 0306-686 \mathrm{x}\end{array}$ http://www.cassknowledge.co.uk/sites/default/files/article-attachments/362 giladlivne_football_jbfa.pdf

Komite Standar Akuntansi Pemerintahan. 2011. Buletin Teknis Standar Akuntansi Pemerintahan Nomor 11 tentang Akuntansi Aset Tak Berwujud. Jakarta: KSAP

2014. Buletin Teknis Standar Akuntansi Pemerintahan Nomor 16 tentang Akuntansi Piutang Berbasis Akrual. Jakarta: KSAP

Biro Perencanaan dan Keuangan. 2011. Laporan Perkembangan Kerugian Negara Tahun Anggaran 2010. Jakarta: Sekretariat Jenderal Kementerian Keuangan

. 2012. Laporan Perkembangan Kerugian Negara Tahun Anggaran 2011. Jakarta: Sekretariat Jenderal Kementerian Keuangan 
2013. Laporan Perkembangan Kerugian Negara Tahun Anggaran 2012. Jakarta: Sekretariat Jenderal Kementerian Keuangan

2015. Laporan Perkembangan Kerugian Negara Tahun Anggaran 2014. Jakarta: Sekretariat Jenderal Kementerian Keuangan

Kardjo, J. 1994. Penyelesaian Kerugian Negara. Jakarta: Eko Jaya

Bzunek, Michael. 2015. How and why the concept of a capital is applied to human beings: in Retrospect. Journal of Economy, Business and Financing, volume 3, issue 1, pp.1-6. http://www.scipub.com/archive/?vid=1\&aid=3\&kid=80301-1\&q=f1

Von Bergen, C.W., dan William T. Mawer. 2007. Recouping training and development costs using preemployment agreements. Employee Responsibilities and Rights Journal, 19(2), pp.127-143. http://link.springer.com/article/10.1007/s10672-007-9039-x (diakses pada tanggal 12 Juni 2015)

Republik Indonesia. 2004. Undang-undang Nomor 1 Tahun 2004 Tentang Perbendaharaan Negara

Presiden Republik Indonesia. 1961. Peraturan Presiden 12 Tahun 1961 tentang Pemberian Tugas Belajar

Kementerian Keuangan. 1999. Keputusan Menteri Keuangan Nomor 508 Tahun 1999 Tentang Petunjuk Pelaksanaan Penyelesaian Kerugian Negara bukan Kekurangan Perbendaharaan di Departemen Keuangan . 2004. Keputusan Menteri Keuangan Nomor 289 Tahun 2004 tentang Ketentuan Ikatan Dinas bagi Mahasiswa Program Diploma Bidang Keuangan di Lingkungan Departemen Keuangan. . 2014. Peraturan Menteri Keuangan Nomor 188 Tahun 2014 Tentang Ikatan Dinas bagi Pegawai Negeri Sipil Lulusan Program Diploma Bidang Keuangan dan Ganti Rugi bagi Mahasiswa dan Lulusan Program Diploma Bidang Keuangan di Kementerian Keuangan . 2014. Peraturan Menteri Keuangan Nomor 213 Tahun 2014 Tentang Perubahan Atas Keputusan Menteri Keuangan Nomor 508/KMK.01/1999 Tentang Petunjuk Pelaksanaan Penyelesaian Kerugian Negara Bukan Kekurangan Perbendaharaan Di Departemen Keuangan. 2015. Peraturan Menteri Keuangan Nomor 251/PMK.06/2015 tentang Tata Cara Amortisasi Barang Milik Negara Berupa Aset Tak Berwujud pada Entitas Pemerintah Pusat

Menteri Pertama. 1961. Keputusan Menteri Pertama Nomor 224/MP/1961 tentang Peraturan Pelaksanaan tentang Tugas Belajar di Dalam dan di Luar Negeri.

Sekretariat Jenderal Kementerian Keuangan, Biro Perencanaan dan Keuangan. 2014. Media Informasi Kerugian Negara: Potret Penanganan Kerugian Negara di Kementerian Keuangan dan Laporan Penyelesaian Kerugian Negara di Kementerian Keuangan $\quad$ Tahun 2013. http://www.setjen.kemenkeu.go.id/sites/default/files/[tittle]-1352014/media informasi_kerugian_negara_potret_penanganan_32885.pdf. (diakses 14 Maret 2015)

Nur, Fadli M, Noor, Fauziah, dan Harahap, Rahmad Karim. 2014. Kapitalisasi Kontrak Ikatan Dinas Sebagai Aset Tak Berwujud Guna Meningkatkan Kualitas Laporan Keuangan Pemerintah. (Karya Tulis) http://kampus4u.blogspot.co.id/2015/06/akuntansi-belanja-modal-dan-aset-tetap.html 